\title{
Gully Migration on a Southwest Rangeland Watershed
}

\author{
H.B. OSBORN AND J.R. SIMANTON
}

\section{Abstract}

Most rainfall and almost all runoff from Southwestern rangelands are the result of intense summer thunderstorm rainfall. Gully growth and headcutting are evident throughout the region. $A$ large, active headcut on a Walnut Gulch subwatershed has been surveyed at irregular intervals from 1966 to present. Runoff at the headcut was estimated using a kinematic cascade rainfall-runoff model (KINEROS). The headcut sediment contribution was about 25\% of the total sediment load measured downstream from the headcut; and the sediment contribution from the swale drainage above the headcut, as estimated from a depth-integrated pumping sampler, was about the same. Although more data are needed to quantify sediment contributions from other tributary watersheds, the total contribution from gully banks and headcuts on Walnut Gulch must be an important portion of the total sediment load.

The $150-\mathrm{km}^{2}$ Walnut Gulch Experimental Watershed, near Tombstone, Arizona, is typical of much of the semiarid rangeland in the southwestern United States. Walnut Gulch is a tributary of the San Pedro River. Most rainfall and almost all runoff from these rangelands are the result of intense summer thunderstorm rains of short duration and limited areal extent. Gully growth and headcutting have been evident throughout the region, including Walnut Gulch. In 1975, a project was initiated to determine the gullyand headcut contribution to sediment loadsat several runoff-measuring stations on Walnut Gulch. One of the principal objectives of the program was to determine the rate of headcut development and the proportional headcut contribution to the total watershed sediment yield. The object of this study was to determine movement and sediment contribution of a major headcut on watershed 63.011, a subdrainage of Walnut Gulch.

\section{Historical Background}

The most intensive study of gully erosion in the United States was carried out by H.A. Ireland, C.F.S. Sharpe, and D.H. Eargle, and published in USDA Technical Bulletin 633 (1939). Although the study area was on the Piedmont of South Carolina, the report serves as a landmark effort in understanding gully erosion and headcut migration elsewhere. In their report, they stated:

"Almost all gullies result from the acceleration of runoff, or from an unnatural concentration of flowing water. Acceleration and concentration of water have been brought about in various ways, and gullies may be classified into several groups on the basis of their origin. Increased amounts of runoff result from overgrazing, burning, deforestation, or denuding of the land by cultivation. Concentration of the runoff is caused by construction of roads and railroads, with their accompanying ditches, by construction of terraces and terrace outlets, by contour plowing followed by breaking-over of furrows during heavy rains, and by stock paths which, in many cases, become rills and gullies. Acceleration of the movement of water in stream channels is sometimes brought about by clearing of brush from the banks, a practice which often results in accelerated bank erosion."

The theory of erosional processes has been covered by many, including Beasley (1972) and Thormes (1980). The mechanisms of erosion and sediment movement from gullies have been reported by others, including Piest, Bradford, and Spomer (1975) and Piest, Bradford, and Wyatt (1975). However, most of the available data

Authors are research hydraulic engineer and hydrologist, USDA-ARS, Southwest Rangeland Watershed Research Center, 2000 East Allen Road, Tucson, Ariz. 85719. Manuscript accepted 27 January 1986.

on gully erosion is from farmlands, rather than rangelands.

The southeastern Arizona geologic record indicates gullying has occurred in the past, but the most recent intense episode of accelerated gullying appears to have begun in the 1880's (Hastings and Turner 1965). Gullies in the 2 major stream channels of southeastern Arizona, the San Pedro and Santa Cruz Rivers, began because of man's activities in the flood plains and were accelerated by increased runoff from overgrazed tributary watersheds. From meandering perennial streams, both the San Pedro and Santa Cruz became incised ephemeral channels. The gullies proceeded to develop from the major channels upward into the tributary watersheds. Gullies migrated well into Walnut Gulch from the San Pedro. The advance of gullies has slowed as the amount of contributing runoff area to each decreased, but a few gullies are still very active. The most active gullies are those with large contributing areas remaining, a result of restricted headcutting at one or more times during the upward migration.

\section{Watershed Description}

Watershed 63.011 ( 824 hectares) is located in the upper part of Walnut Gulch Experimental Watershed. There are 10 weighingtype recording raingages located on, or immediately adjacent to, the watershed (Fig. 1). Runoff stage is measured with an A-35

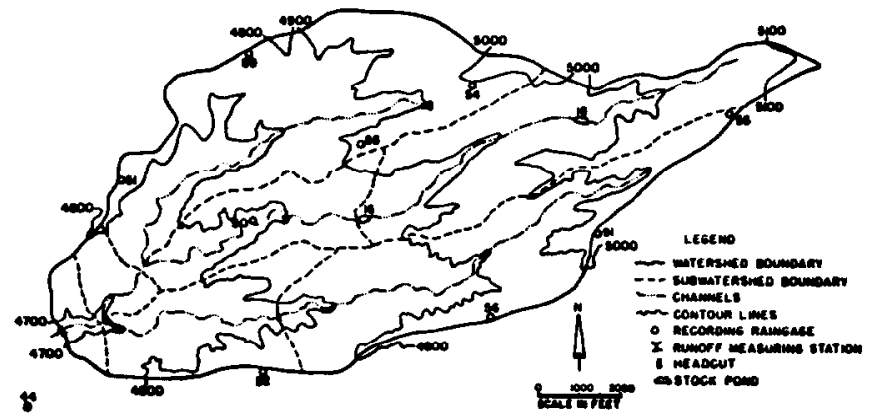

Fig. 1. Contour and description map of subwatershed 63.011, Walnut Gulch.

water-level recorder at a super-critical flume at the watershed outlet. The subwatershed has a mixed grass/brush cover, with the predominant soil a Hathaway-Nickel gravelly loam.

There are 3 major subdrainages on 63.011 , the north, central, and south branches (Fig. 1). The incised sand-bottomed channel reaches almost to the upper end of the north branch. Runoff from the central branch is largely controlled by 2 earthen-diked tanks. The lower of the 2 tanks has overflowed in only 1 of 20 years of record.

An incised sand-bottomed channel extends about halfway up the south branch. At the upper end of the incised channel, a headcut is currently cutting through a broad swale (Fig. 2). The near-vertical walls of the headcut on the south branch average about 2.5 meters in depth (Fig. 3). The swale is predominantly a Comoro sandy loam for the upper 250 to $500 \mathrm{~mm}$, becoming fine gravelly loam below 1 meter, grading into a lightly cemented conglomerate, and finally, a well-cemented caliche conglomerate at 2 to 3 meters.

A depth-integrated-pumping sampler was installed in 1976, in the south branch swale above the headcut. Suspended sediment samples were collected for most runoff events from 1977 through 1982. A measuring station was located in a narrow channel section downstream from the headcut, in 1978. The station consisted of a 


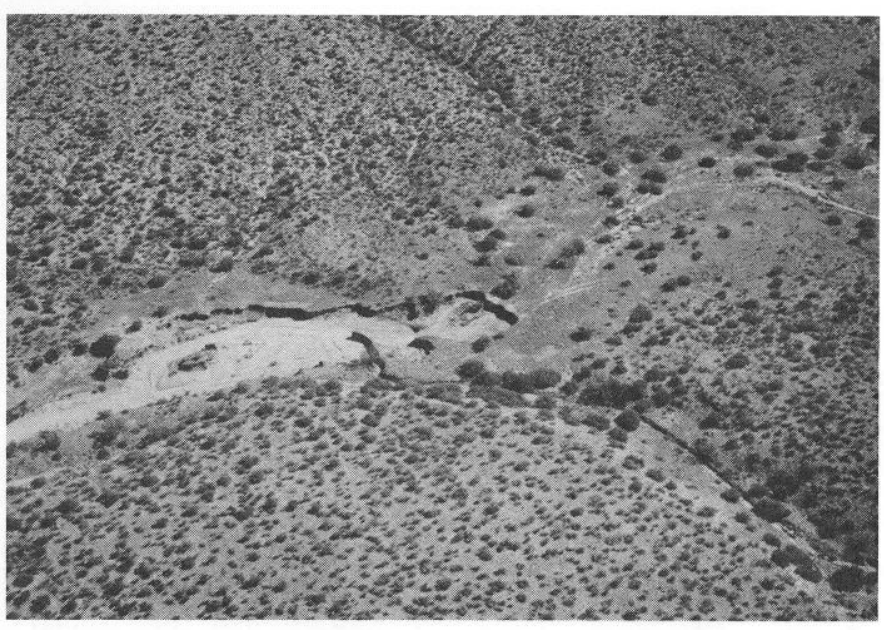

Fig. 2. Headcut on south branch of watershed 63.011, Walnut Gulch, September 1973.

trapezoidal weir, a pump sampler, and a stilling well with an FW-1 water-level recorder. Samples were collected for only 4 events before the station was destroyed by the storm of 27 August 1982 . Only suspended sediment samples were taken, because the swale above the headcut showed no evidence of bedload movement (the channel bottom was grass lined), and there was no practical method of sampling bedload below the headcut.

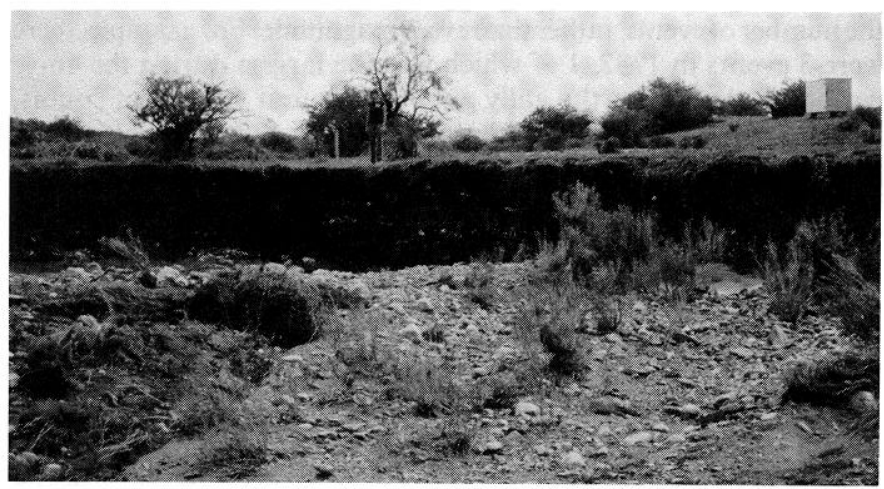

Fig. 3. Upstream face of headcut on south branch of watershed 63.011, Walnut Gulch, September 1982.

\section{Headcut Erosion}

At the time Walnut Gulch was first instrumented (1955), the advance of the headcut on the south branch had been slowed by an unusually well-consolidated conglomerate barrier. Unfortunately, no surveys were made at that time. Apparently, gully growth on the north branch of subwatered 63.011 was not similarly constrained, and the knickpoint had moved much farther up the similar-sized subdrainage. Once the south branch gully had broken through the constraining material, it proceeded to cut rapidly through a broad swale.

The first complete topographic survey of the headcuts was made in 1966. Subsequent topographic surveys were made in 1973, 1976, 1981 , and 1982. The current contributing drainage area above the headcut on the south branch is 200 hectares. In contrast, the contributing drainage above the north branch headcut is only 24 hectares.

Headcuts on Walnut Gulch have tended to be either linear or dendritic. Linear headcuts usually follow old roads or trails. Dendritic headcuts are common in broad swales where gullies progress as fingers along lines of least resistance. On watershed 63.011 , the headcuts are dendritic, with the irregular advance apparently con- trolled primarily by resistance of roots from small trees and large shrubs, rather than by differences in soils. The trees and large shrubs tend to bind the soil beneath them, which then is left to form peninsulas and islands after erosion by the small- to medium-sized runoff events. These are then eroded away by subsequent major events (Fig. 4).

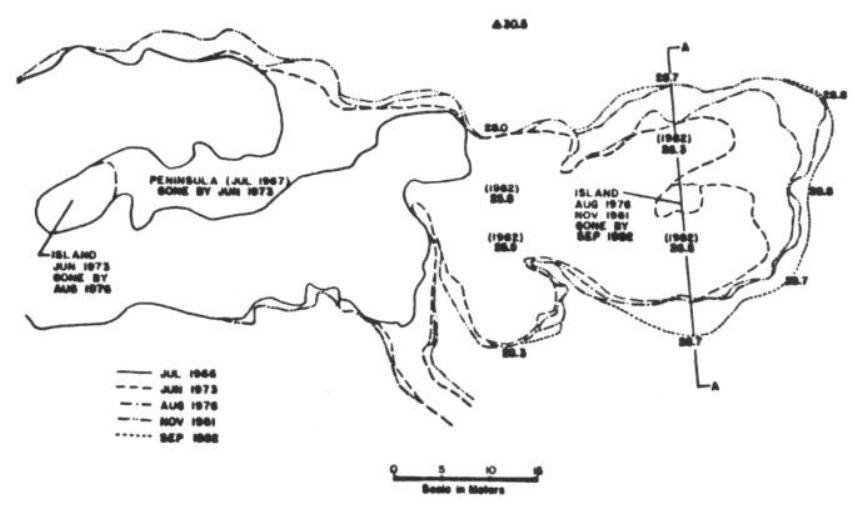

Fig. 4. Headcut migration on south branch of subwatershed 63.011, Walnut Gulch.

The upward migration of the headcut, on the south branch, has been documented from the 5 topographic surveys (Fig. 4). The constantly changing dimensions of the gully below the headcut have also been documented by these surveys (Fig. 4 and 5).

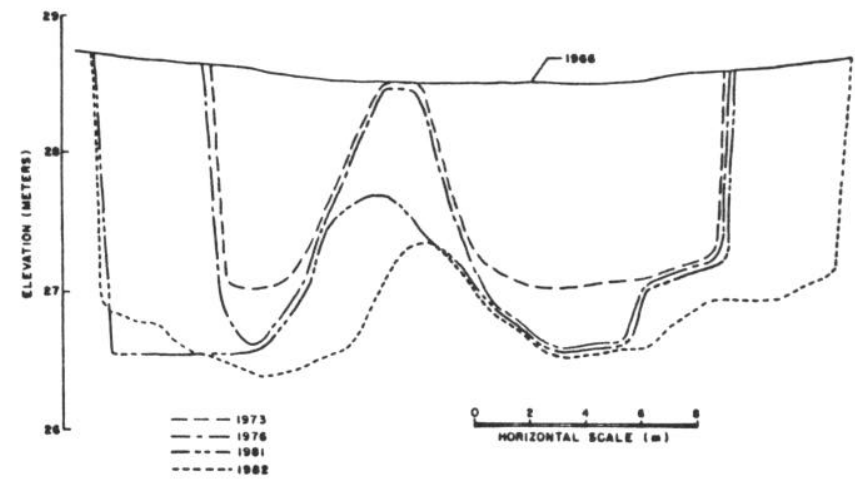

Fig. 5. Cross-section looking upstream, headcut on south branch of subwatershed 63.011, Walnut Gulch.

Between the 1966 and 1973 surveys, the period of most rapid gully growth, about $1,230 \mathrm{~m}^{3}$ of material were removed (Fig. 6). Another $610 \mathrm{~m}^{3}$ were eroded between the 1973 and 1982 survey (Fig. 6), for a total contribution of $1,840 \mathrm{~m}^{3}$.

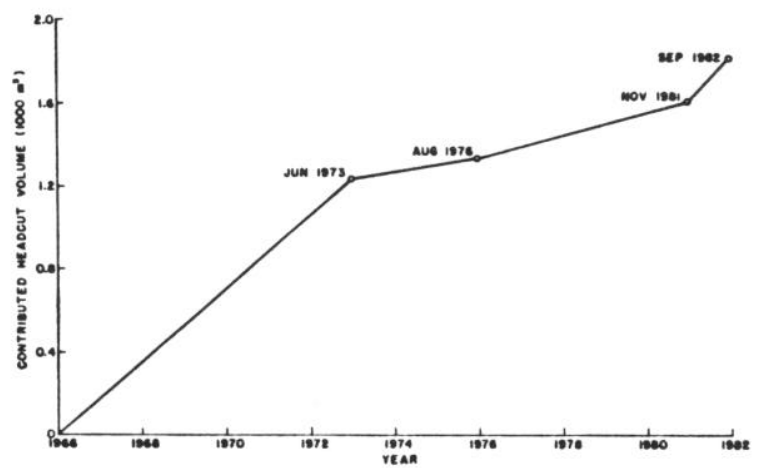

Fig. 6. Sediment contributed from headcut, south branch of subwatershed 63.011, Walnut Gulch, 1966-1982. 
To make a quantitative evaluation of the headcut contribution to total sediment loads, we had to estimate peaks and volumes of discharge above the headcut from 1966 through 1982. To accomplish this, we adapted a kinematic cascade rainfall/runoff model, KINEROS (Rovey et al. 1977; Lane and Woolhiser 1977, Smith 1981). KINEROS includes a subroutine for estimating channel dimensions and infiltrations which can be adapted for both swale and incised channels. Model parameters were determined by matching simulated and actual hydrographs for watershed 63.011 at the watershed outlet. The parameters for the larger watershed were used in simulating the hydrographs for each event on the south branch above the headcut. We felt the watershed above the south branch headcut was large enough and similar enough to the entire watershed to justify using the same parameters. Simulated peaks and volumes for the major events (peaks greater than 3.0 $\mathrm{m}^{3} / \mathrm{sec}$ ) are shown in Table 1 . The 20 major events, between 1966

Table 1. Simulated runoff peaks and volumes (greater than $3 \mathrm{~m} /{ }^{3} \mathrm{sec}$ and $5000 \mathrm{~m}^{3}$, respectively) for a 200-hectare subwatershed above headcut on the south branch of 63.011, Walnut Gulch watershed (1966-1982).

\begin{tabular}{lccccc}
\hline \hline Date & $\begin{array}{c}\text { Est. } \\
\text { Peak }\end{array}$ & $\begin{array}{c}\text { Est. } \\
\text { Volume }\end{array}$ & Date & $\begin{array}{c}\text { Est. } \\
\text { Peak }\end{array}$ & $\begin{array}{c}\text { Est. } \\
\text { Volume }\end{array}$ \\
\hline & $\left(\mathrm{m}^{3} / \mathrm{sec}\right)$ & $\left(1000 \mathrm{~m}^{3}\right)$ & & $\left(\mathrm{m}^{3} / \mathrm{sec}\right)$ & $\left(1000 \mathrm{~m}^{3}\right)$ \\
28 Jul 66 & 6.1 & 11.4 & 27 Jul 66 & 8.3 & 14.9 \\
30 Jul 66 & 15.1 & 29.2 & 5 Sep 76 & 5.5 & 12.9 \\
6 Aug 66 & 3.9 & 8.2 & 31 Jul 77 & 3.0 & 7.9 \\
13 Aug 67 & 5.0 & 8.2 & 1 Sep 77 & 3.1 & 7.1 \\
10 Sep 67 & 24.6 & 41.9 & 5 Sep 77 & 3.0 & 9.5 \\
20 Jul 70 & 13.2 & 18.1 & 4 Aug 80 & 7.5 & 13.3 \\
18 Aug 71 & 4.9 & 14.6 & 15 Jul 81 & 7.3 & 16.8 \\
21 Aug 73 & 3.3 & 5.5 & 10 Aug 81 & 3.9 & 6.6 \\
22 Aug 75 & 7.6 & 11.4 & 27 Aug 82 & 31.0 & 58.2 \\
13 Sep 75 & 4.5 & 9.8 & 11 Sep 82 & 9.5 & 23.3 \\
\hline
\end{tabular}

and 1982 , produced about $330,000 \mathrm{~m}^{3}$ of runoff from the 200 hectare watershed, which was about $75 \%$ of the total runoff volume of $440,000 \mathrm{~m}^{3}$. Runoff volumes were calculated for each year from 1966 through 1982 (Fig. 7), and the accumulated runoff volumes

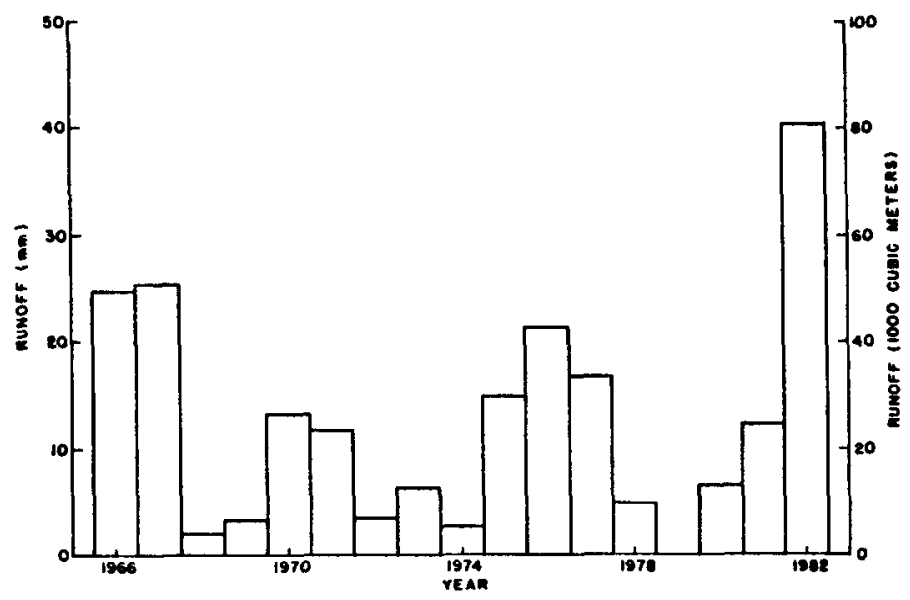

Fig. 7. Simulated annual runoff volumes at headcut on south branch of subwatershed 63.011, Walnut Gulch, 1966-1982.

were compared to the sediment contributed by headcutting for each period between surveys (Fig. 8). Between 1966 and 1973, the headcut sediment contribution amounted to about $0.7 \%$ of the total runoff volume. Between 1973 and 1982, the headcut sediment contribution was about $0.24 \%$ of the total runoff volume.

Piest et al. (1975) noted in a study of midwestern farmlands that headcutting occurred from even fairly moderate events. We attempted, unsuccessfully, to correlate headcut movement with

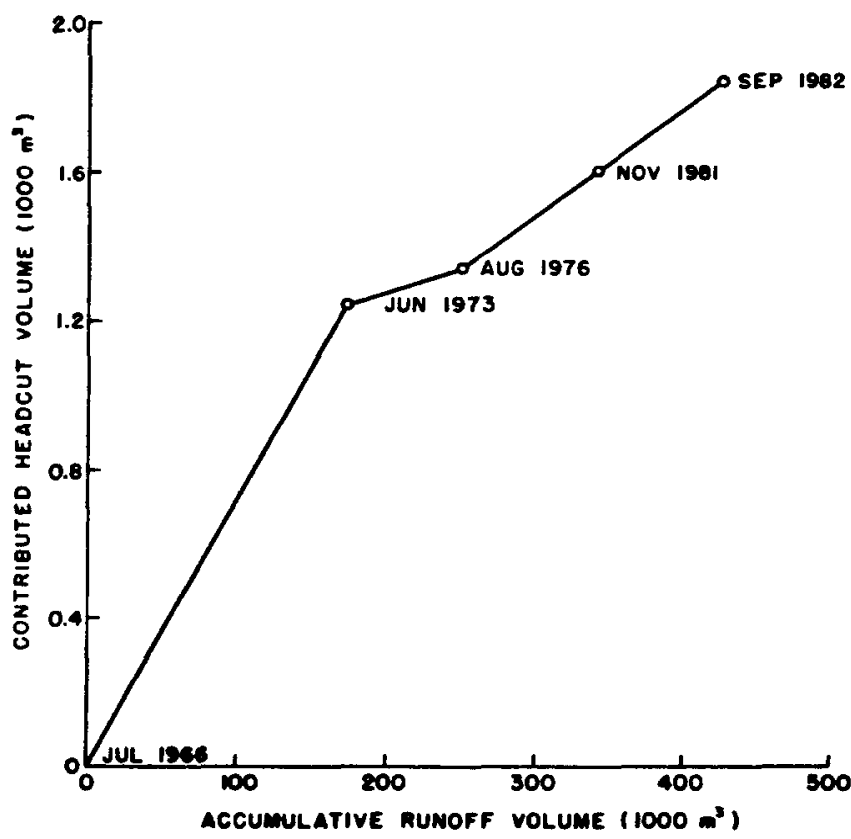

Fig. 8. Comparison of accumulated runoff volumes and contributed headcut sediment volumes on the south branch of of subwatershed 63.011, Walnut Gulch, 1966-1982.

peak discharge. Headcutting appeared to be best correlated with the number of events, rather than event magnitude. For example, there were 3 events in 1982, 1 of which was the largest during the 16-yr period of record; yet the gully growth, per unit volume of runoff, was slightly below average. The near-record event did cause major changes in the gully downstream from the headcut.

Suspended sediment samples were collected in the swale above the headcut for 18 events from 1977 through 1982. Suspended sediment concentration, by weight, varied up to $1.8 \%$, but maximum concentrations were less than $1 \%$ from 16 of the 18 events. There was no evidence of a significant bedload. Based on the available samples and the simulated runoff data, sediment concentration above the headcut averaged about $0.5 \%$. The average total headcut sediment contribution for the same period, based on topographic surveys and simulated runoff, was also about $0.5 \%$ of the runoff volume.

Sediment samples were collected below a concrete weir downstream from the headcut for only 4 events. Sediment in the samples ranged up to $3 \mathrm{~mm}$ in size, and bedload was not measured. Concentrations varied up to $4.8 \%$. From these few samples, and other samples at other flume-weirs on Walnut Gulch, we concluded that suspended sediment concentrations $(\leq 3 \mathrm{~mm})$ averaged about $2 \%$ in the incised channel below the headcut.

\section{Discussion}

Headcutting on Walnut Gulch can produce a significant portion of the sediment load from specific watersheds. On a 200-hectare subwatershed, the estimated headcut sediment contribution was about $25 \%$ of the suspended sediment load estimated from samples collected in the incised channel downstream from the headcut. Suspended sediment contribution from the swale drainage above the headcut was on the same order as the total conribution from the active headcut (as estimated from topographic surveys) - -about $0.5 \%$ by weight. The remaining $50 \%$ resulted from bank sluffing downstream from the active headcut area.

Since the headcut on the south branch of 63.011 is one of the most active on Walnut Gulch, the overall contribution from headcutting on Walnut Gulch is probably less than $25 \%$ of the suspended sediment load. Osborn et al. (1976) found that very small, 
gullied watersheds could produce up to 3 times the total sediment loads as similar-sized nongullied watersheds. More data are needed to quantify these losses on larger watersheds. However, the total contribution from gullies and headcuts is an important part of sediment transport.

\section{Literature Cited}

Beasley, R.P. 1972. Erosion and sediment pollution Control. Iowa State University Press.

Hastings, J.R., and R.M. Turner. 1965. The changing mile. University of Arizona Press.

Ireland, H.A., C.P. Sharp, and D.H. Eargle. 1939. Principles of gully erosion in the Piedmont of South Carolina. USDA Tech. Bull. 633, Washington, D.C.

Lane, L.J., and D.A. Woolhiser. 1977. Simplification of watershed geometry affecting simulation of surface runoff. J. Hydrol. 35:173-190.

Osborn, H.B., J.R. Simanton, and K.G. Renard 1976. Use of the universal soil loss equation in the semiarid Southwest. p. 41-49. In: Soil Erosion: Prediction and Control. Proc. Nat'1. Conference on Soil Erosion, Soil Conservation Soc. of America, Ankeny, lowa.
Piest, R.F., J.M. Bradford, and R.G. Spomer. 1975. Mechanisms of erosion and sediment movement from gullies. p. 162-176. In: Present and Prospectiv Technology for Predicting Sediment Yields and Sources, Proc. Sediment Yield Workshop, USDA-ARS-S-40.

Piest, R.F., J.M. Bradford, and G.M. Wyatt. 1975. Soil erosion and sediment transport from gullies. J. Hydraulics Div., Proc. ASCE, 101(HY1):65-80.

Rovey, W.W., D.A. Woolhiser, and R.E. Smith. 1977. A distributed kinematic model of uplant watersheds. Hydrology Paper No. 93, Colorado State University, Fort Collins, Colorado.

Smith, R.E. 1981. A kinematic model for surface mine sediment yield. Trans. ASAE Special Edition. Vol. 24:1508-1514.

Thornes, J.B. 1980. Erosion processes of running water and their spatial and temporal controls: A theoretical viewpoint. p. 129-182. In: Soil Erosion, edited by M.J. Kirby and R.P.C. Morgan. John Wiley and Sons, New York, N.Y. 